\title{
An Analysis of Willingness to Pay on Visitors of Mangrove Forest at Sicanang - Belawan Ecotourism
}

\author{
Eka Putri Wardani ${ }^{1, *}$, Saidun Hutasuhut ${ }^{1}$, Rahmat Mulyana ${ }^{1}$ \\ ${ }^{1}$ Faculty of Economics, Universitas Negeri Medan, Indonesia \\ ${ }^{*}$ Corresponding Author. Email: eputriwardani@gmail.com
}

\begin{abstract}
The aims of this research are to calculate and analyze influence of travel cost, income, distance, education, age and facilities to the number of tourist visit at Sicanang Belawan Mangrove Forest Ecotourism. The research samples conducted using by the random sampling method was choosing in a random from mangrove forest visitors. This study applied Travel Cost Method (TCM) for measuring economic valuation of mangrove forest at Sicanang, Belawan. The result showed that the three independent variables i.e. income, travel cost and distance had an effect the number of tourist visits. The total economic value of mangrove forest beach is Rp. 2,913,450,00 and willingness to pay is $\mathrm{Rp} 30.000 /$ person,
\end{abstract}

Keywords: Economic Value, Travel Cost Method, Mangrove Forest Beach, The Number Of Visits

\section{INTRODUCTION}

Tourism for the time being especially in Indonesia has been considered to be a very important sector .But as far as being the driving force of the because in the economy sector , tourism was also considered as one of the interesting things to reduce unemployment caused by plenty of once tourism can placed wherever. The tourism sector have tickle-down effect to the npls in other sectors like industry the craft, food , hospitality , so that in tourism bureau will be able to create jobs and to raise the income.

Mangrove ecotourism Sicanang ecotourism is located in the city of Medan, North Sumatra Indonesia. Mangrove ecotourism is a form of tourist travel to the trees that are still natural and tourists coming to do not only tourist, alone but with the objective of education, nature conservation and preserving the.The village had Sicanang - Belawan area 1550 $\mathrm{Ha}$ region mangrove forest that remains is $450 \mathrm{Ha}$, good potential including ecotourism area.

Urban village Sicanang - Belawan feel the impact of the village is the existence of ecotourism mangrove Sicanang because urban village Sicanang - Belawan, ecotourism is the area so the automatic ecotourism mangrove Sicanang was able to impact local residents is particularly the urban village Sicanang - Belawan. The impact may be increasing the income of the, employment and business opportunities and others that could boost the economy surrounding.

To present forest mangrove Sicanang - Belawan itself has increased, according to management itself visitors fell at the time the covid 19 forest mangrove in Indonesia that hit the tourism activity should be closed until months now and new reopened after the initial June 2020 or some after Eid 2020.

Table 1. Data tourist visits to Forest Mangrove Sicanang ecotourism from June - December 2020

\begin{tabular}{|l|c|}
\hline Month & Number of Visitors \\
\hline June & 876 \\
\hline July & 1273 \\
\hline August & 2347 \\
\hline September & 2760 \\
\hline October & 3465 \\
\hline November & 4321 \\
\hline December & 5234 \\
\hline
\end{tabular}

Source: Mangrove Forest Management 2020

The diversity of tourism potential should, managed well proper and too wise. So that it can become one of the regional economic sector in general, and in particular to the economy in society itself. To develop a tourist destination with the management of resources in a way that can be done through the optimal tariff entered with the value of the benefit is felt by the tourists including maintenance fee. Tourist destinations and may also, for consideration in the decisionmaking of management and development of potentials owned a tourist destinations then surely it is important to recognize what factors affecting the economic benefits of a attraction and a response that some people in there were changes the entrance of a tourist attraction.

Look at the tourist mangrove forest of admission price paid by visitors of $\mathrm{Rp} 10.000,00 /$ person and it is nothing 
compared to the cost of management and development of coastal mangrove forest tourism. So it is reasonable to ecotourism economic value calculated by using the method mangrove forest Sicanang (TCM) travel cost method.

A method of traveling expenses (Travel Cost Method) method usually performed by using information about the amount of money or cost and time used to achieve recreation center to estimate the magnitude of benefit from the change in the quality of the environment from recreation center visited [44].

Visitors on a tour or a tourist who is visiting along with the economic value in tourist destinations using travel cost method (TCM) will get consumer surplus mangrove forest visitor attraction of the function of and the demand curve formed. Consumer surplus that actually evaluate visitors still receive surplus (excess) benefits from the price set by the tour ticket that tourist, and that actually tour ticket can still be improved for maintenance and further development the attraction.

The curve of tourist demand can also show the ticket price maximum tourism still to be applied by the tour. The economic value in general is defined by the number of maximum measurements of someone who want to sacrifice goods and services to obtain other goods and services. The concept of a kind of it is called to the wishes pay (willingness to pay) someone on goods and services produced by natural resources and environment [7].

\section{LITERATURE RIVIEW}

As a means of recreation and education, forest mangrove very closely related to visitors. Because it is very important for management to see how the character of, every visitor information about whether their mangrove forest, education benefits obtained following visit forest mangrove and other benefits in a can by visitors directly to forest mangrove. The results of the investigation and research, characteristic perception visitors are expected to provide additional information that could be used as one of the bases in setting policy management services.

Visitors coming to do tourism activity bring traveling expenses as the transportation, consumption, parking and other expense besides the ticket cost .In addition to traveling expenses, can also affected by socio economic factors, are the total income, education level, age, sex.

\section{METHODOLOGY}

The research was conducted in mangrove Sicanang ecotourism in Sicanang - Belawan, of the city of Medan, the Province of North Sumatra. The data used in this research is by using quantitative research, where data obtained was that in the form of a figure that then analyzed in order subsequently in a data analysis. The data used in this research was the primary data was where data primary represents data obtained or obtained directly from the source , the data were drawn and noted for the first time.
This is the kind of research by the quantitative research survey. To research this time also sample collection technique using simple random sampling techniques where this is a random sample [29]. using:

One of the methods used in determining samples is by

$$
\begin{aligned}
& n=\frac{N}{1+N e^{2}} \\
& \text { Information : } \\
& \mathrm{n}=\text { sample } \\
& \mathrm{N}=\text { population } \\
& \mathrm{e}=\text { standard deviations error } \\
& \mathrm{n}=\underline{5234} \\
& \quad \begin{array}{l}
1+5234(0,1)^{2} \\
=
\end{array}
\end{aligned}
$$

The method of analysis that used in this research was with the methods OLS, namely test linear regression multiple by the use of a analysis SPSS 16. Test linear regression multiple is used to know the relation between variables income, the costs to transport, mileage, education, age, and facilities to the number of visits in ecotourism Sicanang - Belawan mangrove forest and expressed function as follows:

$\mathbf{Y}=\mathbf{f}\left(\boldsymbol{X}_{1}+\boldsymbol{X}_{2}+\boldsymbol{X}_{3}+\boldsymbol{X}_{4}+\boldsymbol{X}_{5}+\boldsymbol{X}_{6}\right)$

The model was systematically can be used as follows:

$$
\begin{aligned}
\mathrm{Y}=\boldsymbol{\alpha}+\beta_{1} \operatorname{Ln} X_{1}+\beta_{1} \operatorname{Ln} X_{2}+X_{3} \beta_{3}+X_{4} \beta_{4}+X_{5} \beta_{5}+X_{6} \beta_{6}+\mathrm{e} \ldots \ldots . .(2) \\
\operatorname{Ln} X_{1}=\text { variabel pendapatan (Rp) } \\
\operatorname{Ln} X_{2}=\text { variabel biaya perjalanan (Rp) } \\
X_{3} \quad=\text { variabel jarak tempuh (Km) } \\
X_{3} \quad=\text { varibel pendidikan (tahun) } \\
X_{3} \quad=\text { variabel usia (tahun) } \\
X_{3} \quad=\text { fasillitas (skala likert) } \\
\mathrm{E} \quad=\text { error term }
\end{aligned}
$$

A knowing manner economic value ecotourism mangrove forests in Sicanang - Belawan by using the method travel expenses (travel cost method), the basic concept of a method of travel expenses is time and travel expenses paid by tourists to the visiting sights.

In the use of a method of the costs to transport the that have been carried out using the survey of the questionnaire was visitors about the costs to transport the that must be ejected into tourism location, a visit to the places other and social factor.

To test hypotheses and analysis of data can be through 
with classical test that includes: 1) test normality 2) test multicollinearities 3) heteroskedasticities test.

Next can be done with a covering: 1) test the influence of simultaneous (testF) 2) partial test (testT) 3) test the coefficients determined $\left(\mathrm{R}^{2}\right)$.

Data collection technique used in this research was:

a. Interview: the technique data collection done by means of hold question and answer directly orally against respondents.

b. the technique data collection done by granting some question that is to be answered by community as respondents.

\section{Variables Definition}

a. The number of tourist visits - This variable is the dependent variable. The number of tourists visits the frequency of visits to coastal mangrove forest.

b. Traveling expenses - The traveling expenses are part variable free, traveling expenses considered important and theoretically the traveling expenses certainly will affect the visit. More traveling expenses will the less the number of tourists to visit ecotourism forest mangrove tourism objects. (rupiah in unit).

c. Income - Income travelers included as variable freely as in this research the cost of income tourists is the variable that are considered important and affecting the number of visits theoretically. The higher income tourists the more many requests tourist visits to tourism objects mangrove forest with other words the number of visits also will increase. (in a unit of rupiah).

d. Distance - The distance between their house's tourists from an object or recreation tourism the said it will be the lower services recreation parks to the demand for an object will low including tourism [40]. (in unit kilometers).

e. The age - The age of tourists is the age of visitors expressed and a unit of years. Expected the higher age tourists so the level of tourists visit will also be reduced.

f. Higher education - High levels of education will increase demand for tourism. The education based on length of time would be classified as educated as follows: (The end of elementary school $=6$ year; Junior high school graduate $=9$ year; high school year $=12$ years; from diploma $=15$ years; from an undergraduate degree from $=16$ year; graduate $=18$ years

g. Facilities - Facilities in the study is the perception of visitors who have visited tourist attraction ecotourism activities of the means, mangrove forest infrastructure and the completeness of. tourist attractions. This facility is variable is dummy variable, where its requirements as follows: $(0=\operatorname{not} \operatorname{good} 1=$ good $)$

\section{RESULT AND DISCUSSION}

Test $\mathrm{F}$ in regression analysis multiple linear used to know whether all independent variable can affect in dependent on variables. Test $\mathrm{F}$ may be done by means compare in value significant with the critical 0,05 .

When the significance $>0,05$; so, the result is to be received or can be independent variable in simultaneous not significant dependent on variables. And if the significance < 0,05 so it the result is in refuse or independent variable simultaneously significant dependent on variables.

Table 2. Regression Test Result

\begin{tabular}{|l|c|r|r|r|}
\hline \multicolumn{1}{|c|}{ Model } & df & $\begin{array}{c}\text { Mean } \\
\text { Square }\end{array}$ & F & Sig. \\
\hline 1 & 6 & 6.891 & 4.689 & $0.000^{\mathrm{a}}$ \\
$\begin{array}{l}\text { Regression } \\
\text { Residual } \\
\text { Total }\end{array}$ & 93 & 1.469 & & \\
\cline { 2 - 5 } & 99 & \multicolumn{3}{|l}{} \\
\hline
\end{tabular}

From the table above known are the significant 0,000 regression models to simultaneously, and the value is smaller than significance (5\%) 0,05 level. So, it can be concluded that simultaneously significant impact on the independent variable dependent variable.

Test the coefficients determination used to identify the ability the regression equation is linear multiple so that it can be know the level explanation model dependent on variables

Terminated in adjusted the value of the regression used to know the amount of variability dependent variable, value ranges from $0-1$ are close to the independent variable 1 the more able to explain the dependent variable.

Table 3. Coefficient Determination Test Result

\begin{tabular}{|c|c|c|c|c|c|}
\hline Model & $\mathrm{R}$ & $\begin{array}{c}\mathrm{R} \\
\text { Square }\end{array}$ & $\begin{array}{c}\text { Adjusted } \\
\text { R Square }\end{array}$ & $\begin{array}{c}\text { Std. Error } \\
\text { of the } \\
\text { Estimate }\end{array}$ & $\begin{array}{c}\text { Durbin- } \\
\text { Watson }\end{array}$ \\
\hline 1 & $0.482^{\mathrm{a}}$ & 0.232 & 0.183 & 1.212 & 2.257 \\
\hline
\end{tabular}

Determination on multiple regression equation said the ability to show the model of a dependent variable. Namely the 0,232 or $23,2 \%$ meaning dependent variable can be explained by the independent variable in this research by percent and the 23,2 and 76,8 \% described by other factors outside model.

T-test aimed at ascertaining the influence of the independent variable individually in makes clear the dependent variable variations. If a value $\mathrm{T}>$ it a significant degree $(0,05)$ then the independent variable individually significant impact on the dependent variable, but if the value of $\mathrm{T}<\mathrm{a}$ significant degree $(0,05)$ then the independent variable individually will not affect the dependent variable. 
Table 4. T-test result

\begin{tabular}{|l|c|c|}
\hline \multicolumn{1}{|c|}{ Variable } & T-count & Sig \\
\hline Constant & 1,327 & 0,188 \\
\hline LnINC (Income) & $-2,303$ & 0,024 \\
\hline LnTC (Transport Cost) & 2,151 & 0,034 \\
\hline EDUCATION & $-1,557$ & 0,123 \\
\hline DISTANCE & $-2,685$ & 0,005 \\
\hline AGE & 0,377 & 0,707 \\
\hline FACILITY & 0,595 & 0,553 \\
\hline
\end{tabular}

Based on the results of test $t$ can be explained as follows:

a. The value of probability (a sig) on the variables of a total income of 0,024 where this intention smaller than a significant degree 0.05 this showed that income variable significant impact on the number of visits.

b. The value of probability (a sig) on the variables of the costs to transport the 0.034 or lower prices than 0.05 showed that the costs to transport the variable influential significant on variables the number of visits. And this is to improve showed that the number of tourist visits can be done by reduce the costs to transport the sectors such as the cost.

c. The value of the probability of (sig) education on the variables of 0,123 or greater than 0,05 stated that the variable education was not significant impact on the number of variables visit.

d. The probability (sig) on the mileage of 0,005 that is smaller than the significance of 0,05 stating that distance variable significant on variables the number of visits tourism.

e. The value of the probability of ( $\mathrm{sig}$ ) on variables the age of as much as 0,707 or greater than 0,05 stated that the variable age no significant impact on the number of visitors to Sicanang ecotourism activities

f. The value of probability (a sig) on the variables of 0,553 facilities as much as greater than the level of significance 0.05 showed that of facilities variables has no significant impact on the number of visits variable.

Based on the results of found on can be explained in column sig. If the result of the regression done produce independent variable for which a significant variable dependent on the variable income, variable travel expenses and variable mileage.

The regression equation as follows:

$$
\begin{aligned}
& \mathrm{Y}=\mathrm{a}+\mathrm{INC}+\mathrm{TC}+\mathrm{EDU}+\mathrm{DIST}+\mathrm{AGE}+\mathrm{FAS}+\mathrm{e} \\
& \mathrm{Y}=4,907-0,489 \mathrm{INC}+0,551 \mathrm{TC}+0,064 \mathrm{EDU}- \\
& 0,034 \mathrm{DIST}+0,005 \mathrm{AGE}+0,153 \mathrm{FAS}+\mathrm{e} \\
& \text { Information: }
\end{aligned}
$$

$\begin{array}{ll}\mathrm{Y} & : \text { Number of visits } \\ \mathrm{a} & : \text { Constant } \\ \text { INC } & : \text { Income of an individual } \\ \mathrm{TC} & : \text { Travel Cost } \\ \text { EDU } & : \text { Education } \\ \text { DIST } & : \text { Distance } \\ \text { AGE } & : \text { Age } \\ \text { FAS } & : \text { Facilities } \\ \mathrm{e} & : \text { Residual / error }\end{array}$

Of the estimation results of regression in the model was collected as much as 4,907 constant value. The economic value ecotourism activities mangrove forest Sicanang by using a method of travel cost (travel cost) is follows:

Total value: Average Value x Population

$$
1000
$$

Information:

Average Value $=$ The costs to transport the maximum

The population $=$ Population of Sicanang - Belawan

$\frac{\frac{\text { Average Value x Population }}{1000}}{\frac{150.000 \times 19.423}{1000}}$
$=2,913,450,00$

Based on the calculation on obtained that economic value forest mangrove Sicanang belawan with visits 1000 the Rp.2,913,450.00 by a willingness to pay by $30.000 /$ person.

\section{Test Results Interpretation}

Interpretation of the adjustment variable explanation income on variables using model linear regression will be explained below:

Variable income has influence negative and been inspected by the number of tourist visits Mangrove Forest at Sicanang - Belawan ecotourism, the and the significance of the 0,024 of $-0,489$. The higher income someone to can enjoy tourism objects will the tourist visit to mangrove coast. And for based on research conducted by the majority of respondents are in the environment the places hutan mangrove average income. This is in accordance with research conducted by [16] said that a variable influential negative and significant income on variables the visit.

Variable traveling expenses that had spent by someone have had a positive impact on variables the visit and significant ecotourism mangrove Sicanang the significantly by 0,034 of and the 0,554 . The large outlay traveling expenses someone will increase the number of tourist visits, it is because based on the research made the majority of respondents are in tourism environment distance from home to tourism place was in less than hour and at most only an hour. 
Variable mileage from their homes to the ecotourism mangrove forests Sicanang show negative impact and significant on variables the tourist visits mangrove forest with the significant 0,005 and value of $-0,034$ coefficient. With that the longer the journey for someone to the tour the number of a visit to the places could decrease. This is because visitors prefer the attraction having mileage faster than the places his mileage longer than the shelter tourists. And accessibility and quality of the road to tourism mangrove ecotourism Sicanang needs to be improved thereby increasing number of tourists visit.

\section{CONCLUSION}

Based on the results of research, it can be concluded that:

a. Economic value mangrove forest Sicanang - Belawan with visits 1000 residents are as big as rp.2,913,450.00 by a willingness to pay as much as 150.000 . per person.

b. Of the research that has been carried out test multiple linear regression using six independent variables obtained three independent variables for which a significant impact on his, dependent variable the variable, income variable traveling expenses and variable mileage

c. Variable negative and significant income have influence on variables the visit and increase selling the regression coefficient who negative which is $-0,489$ who shows that the higher income someone to will visit and traveled to tourism objects mangrove so can reduce the tourist visit to the object, this is still in research environment tourism destinations that flattened income

d. The travel expenses led to a positive and significant on variables the visit with the coefficient of 0,554 where the travel expenses incurred by someone in traveled will affect the number of tourist visits to tourism mangrove forest.

e. Variable mileage having negative and significant influence on the number of tourist visits, the coefficient of $-0,034$ who explained that the longer the journey for tourists to the attraction forest mangrove will decrease the number of tourist visits, because someone traveled to seek the places that are close to home tourists.

f. Education variable influence negative and insignificant to the number of visitors to tourism mangrove forest, and suggests that all uneducated among the highly educated can enjoy and traveled to tourism mangrove forest

g. Variable age has had a positive impact and insignificant on variables the number of tourist visits, tourists and tourism objects mangrove can be enjoyed by all the circles age.

h. Facility variable have had a positive impact and significant on variables the number of tourist visits that is indicative of the increased availability of facilities tourism to increase tourist visits and make tourists feel comfortable for a longer visit to tourism location mangrove forest.

\section{REFERENCES}

[1] Anasthacia, N. Analysis demand tourists tourism karimunjawa national park , district Jepara . Skripsi not posted, at Diponegoro University. 2014

[2] Arief, A., Functions and benefits mangrove forest Yogyakarta: Kanisius, 2003.

[3] Bengen, D. G., Sinopsis Ekosistem dan Sumber Daya Alam Pesisir dan Laut serta Prinsip Pengelolaannya. Bogor: PKSPL-IPB, 2001.

[4] Dahuri, Pengelolaan Sumberdaya Wilayah Pesisir dan Lautan Secara Terpadu. Jakarta: PT. Pradnya Paramita, 2001.

[5] Djijono. Valuasi Ekonomi Menggunakan Metode Travel Cost Taman Wisata Hutan di Taman Wan Abdul Rachman, Propinsi Lampung. In Makalah Pengantar Falsafah Sains. Program Pasca Sarjana. Institut Pertanian Bogor. Djuanda dengan menggunakan Pendekatan Travel Cost Method.skripsi. Bogor: Fakultas Ekonomi dan Manajemen Institute Pertanian Bogor, 2002.

[6] Fauzi, A., Ekonomi Sumber Daya Alam dan Lingkungan. Jakarta: PT Gramedia Pustaka Utama, 2004.

[7] Fauzi, A. Ekonomi Sumber Daya Alam dan Lingkungan Teori dan Aplikasi. Jakarta: PT Gramedia Pustaka Utama, 2010 .

[8] Flanagan, e. Labor Economis and Labor Relationst. United State of America: Scott, Foresman and Company, 1984.

[9] Foyen, R. T., Macroeconomics Theories and Policies. New York: Macmillan Publishing Company, 1990.

[10] Ghazali, I., Aplikasi Analisis Multivariate dengan SPSS, cetakan keempat. Semarang: Badan Penerbit Universitas Diponegoro, 2006.

[11] Gibson.H. Sport Tourism: A critical analysis of research. Sport Management Review, I, 1998, pp 45-76.

[12] Gilarso. Pengantar Ilmu Ekonomi Mikro. Yogyakarta: Kanisius. Gravitiani, evi. Valuasi Ekonomi Area Stadion Kridosono Yogyakarta, vol 38-50, 2008.

[13] Gujarati, D., Dasar-dasar Ekonometrika, Terjemahan Mangunsong, 2012.

[14] Jakarta: R.C. Salemba Empat buku 2 edisi 5.

[15] Irwanto, Keanekaragaman Fauna pada Habitat Mangrove. Yogyakarta, 2006.

[16] Jati. Valuasi Ekonomi Pantai Srau Kabupaten Pacitan dengan Pendekatan Travel Cost Mehod, 2016.

[17] Jonshon, D. d., Eucalyptuspelita wild. Australia: Forest Scientist and Consultans, 1987. 
[18] Leiper, N., Tourism System: An Interdisciplinary Perspective. . New Zealand: Departement of Management System, Massey University, 1990.

[19] MacNae. W., A general account of the fauna and flora of mangrove swamps and forest and the indo-west-pacific region. Advance in marine Biology, 6: 1968, pp 73-270.

[20] Matheison, A. \&. Tourism: Economic, Physical and Social Impact. New York: Longman Scientific and Technical, 1982.

[21] McIntosh, R., Tourism: Principles, Pratcties, Philosophies. USA: Grid Punlishing Inc., 1995.

[22] Morrion, M. d., The Tourisme System. New Jersey: Prentice Hall, Inc. Morrison. 1985.

[23] Mujianto. A., valuasi Ekonomi Obyek Wisata Pantai Teluk Penyu Kabupaten Cilacap: Pendekatan Travel Cost Method. skripsi Jurusan Ilmu Ekonomi Fakultas Ekonomi Universitas Muhammadiyah Yogyakarta, 2012.

[24] Pendit, N., Wisata Konvensi. Jakarta: PT, Gramedia Pustaka Utama. 1999.

[25] Porter, G. d. Dasar-dasar Ekonometrika. Jakarta: Salemba Empat., 2012.

[26] Pramujaya, R. A., Valuasi Ekonomi Taman Rekreasi Sengkaling dengan Aplikasi Travel Cost Method di Kabupaten Malang, 2016

[27] Rahmadani. Valuasi Ekonomi Objek Wisata Tanah Lot dengan Aplikasi Travel Cost Mtehod dan Contigent Valuation Method, 2014

[28] Rodger. D., Leisure, Learning and Travel. Journal of Physical Education, Research and Dance, 69(4), 1998. pp, 28-31.

[29] Rukmana, A. D., Valuasi Ekonomi Ekowisata Gardu Pandang Ketep, Kabupaten Magelang. Skripsi Universitas Muhammadiyah Yogyakarta, 2014.

[30] Sahlan. (2008). Valuasi Ekonomi Wisata Alam Otak Kokok Gading dengan Pendekatan Biaya Perjalanan. Skripsi Program Sarjana Universitas Mataram.

[31] Samsudin, N., Valuasi Nilai Ekonomi Taman Nasional Bunaken dengan Aplikasi Travel Cost Method. 2012.

[32] Santoso, N., Pola Pengawasan Ekosistem mangrove. Jakarta: Lokakarya Nasional Pembangunan Sistem Pengawasan Ekosistem Laut. 2000.

[33] Sekaran, U. Metode Penelitian Untuk Bisnis, Edisi Keempat. Jakarta: Selemba Empat. 2006.

[34] Sendi, B. d., Leisure time in economic evaluation: theoretical and practical considerations. Switzerland: Basel Institute, 2004.

[35] Sinclair, M. T., Economic Of Tourism. London: Routledge. Spillane, J. Pariwisata Indonesia. Yogyakarta: Kanisius, 1997.
[36] Sukadji, S. Psikologi Pendidikan dan Psikologi Sekolah. Depok: Lembaga Pengembangan Sarana Pengukuran dan Pendidikan Psikologi., 2000.

[37] Sukirno, S., Mikro Ekonomi Teori Pengantar. Jakarta: PT Raja Grafindo Persada, 2005.

[38] Sukirno, S., Mikroekonomi Teori Pengantar, Edisis Ketiga. Jakarta: Rajawali Pers, 2010.

[39] Suliyanto, Analisis Statistik-Pendekatan Praktis dengan Microsoft Excel.Yogyakarta: Andi-Yogyakarta, 2012.

[40] Suparmoko, M., Ekonomika Lingkungan, Edisi Pertama. Yogyakarta: BPFE, 2000.

[41] Susilowati, S. d., Analisis Permintaan Objek Wisata Alam Curug Sewu, Kabupaten Kendal dengan pendekatan Travel Cost. Jurnal Dinamika Pembangunan, Vol 1 No.2., 2004

[42] Torkildsen, G., Leisure and Recreation Management: fourth edition.London, 1999.

[43] Tuban, P. P., Data Jumlah Pengunjung Wisata. (L. Brilian, Interviewer)., Agustus 23, 2017.

[44] Yakin, A., Ekonomi Sumberdaya Alam dan Lingkungan Teori dan Kebijaksanaan Pembangunan Berkelanjutan. Jakarta: Penerbit Akademika Presindo, 1997.

[45] Yoeti, O. A., Ekonomi Pariwisata. Jakarta: Kompas, 2008.

[46] Yuliadi, I., Perekonomian Indonesia: Masalah dan Implementasi kebijakan. Yogyakarta: UPFE, 2007.

[47] Zulpikar, Valuasi Ekonomi Objek Wisata Berbasis Jasa Lingkungan Menggunakan Metode Biaya Perjalanan di pantai Batu karas Kabupaten Pengandaran, 2016. 